\title{
Notes of the occurrence in Poland of the rare tineid moth Scardia boletella (Fabricius, 1794) (Lepidoptera: Tineidae)
}

\author{
Jarosław BURY ${ }^{1}$, Marek HoŁOWIŃSKI ${ }^{2}$, Tomasz JAWORSKI ${ }^{3}$, Mariusz MLECZAK ${ }^{4}$, Witold ZAJDA ${ }^{5}$ \\ and Roman ZAMORSKI ${ }^{6}$ \\ ${ }^{1}$ Markowa 1498, 37-120 Markowa, Poland,e-mail: jarekbury2@wp.pl; \\ ${ }^{2}$ Polna 5, 22-235 Hańsk, e-mail: holowinskim@tlen.pl \\ ${ }^{3}$ Department of Forest Protection, Forest Research Institute, Sękocin Stary, Braci Leśnej 3, 05-090 Raszyn, Poland, \\ e-mail: t.jaworski@ibles.waw.pl \\ ${ }^{4}$ Nowy Dworek 41,66-200 Świebodzin, Poland, e-mail:mmleczak@o2.pl \\ ${ }^{5}$ Institute of Systematics and Evolution of Animals, Polish Academy of Science, Stawkowska 17, 31-016 Kraków, \\ Poland,e-mail: zajda@isez.pan.krakow.pl \\ ${ }^{6}$ Wegierska 50/3 38-300 Gorlice,Poland, e-mail: roman_zamorski@op.pl
}

\begin{abstract}
Review of literature data as well as new distributional records of the relict and endangered saproxylic tineid moth Scardia boletella (Fabricius, 1794) in Poland are presented. Unpublished museal data from 1954 to 1963 and own observations from 1988 to 2014, mainly from Bieszczady Mts, East Beskid, Masurian Lake District, Białowieża Forest and Podlasie are included. The species is recorded for the first time from Lublin Upland.
\end{abstract}

Key words: saproxylic insect, relict species, distribution range, conservation, faunistics

\section{INTRODUCTION}

The fungus moth Scardia boletella (Fabricius, 1794) is a species belonging to the family Tineidae Latreille, 1810, subfamily Scardiinae Eyer, 1924, and genus Scardia Treitsche, 1830, represented globally by six species (Robinson 2009). S. anatomella (Grote, 1881) occurs in Canada, the United States of America and Venezuela, S. assamensis (Robinson, 1986) is known from Assam province in India, S. amurensis (Zugulajev, 1965) from the Rusian Far East (Amur Region and Primorsky Krai), China and Japan, as well as from the United States of America where the species was introduced, S. alleni (Robinson, 1986) from Brunei and Sulawesi, S. caucasica (Zugulajev, 1965) from the Caucasus and S. boletella (Fabricius, 1794) which has Euro-Siberian distribution (Robinson 1986, 2009, Buszko 2004, Gaedike 2011, Landry et al. 2013). Few fossil forms similar to the genus Scardia were also described by Kuznetzov (1941) from Baltic amber which origin is from ca. 40 million years ago.

In Europe, the distribution area of $S$. boletella covers 21 countries (Fig. 1) and extends from southern and central parts of Scandinavia and the European part of Russia, through Lithuania, Latvia and Estonia, Belarus, Ukraine, Poland, Germany, Czech Republic, Slovakia, Austria, Hungary, Romania, Slovenia, Croatia, Bosnia and Herzegovina, to the northern part of Italy and Greece (Petersen 1957, 1969, Zagulajev 1973, Jalava 1977, Petersen, Gaedike 1979, Aarvik, Mitdgaard 1982, Robinson 1986, Buszko 2004, Laštůvka \& Liška 2011, Lesar \& Govedič 2010, Pastoralis 2010, Gaedike 2011). This species was also recorded from Switzerland at the beginning of the last century (Rebel 1901), but since then there is no evidence on its presence in this country. 


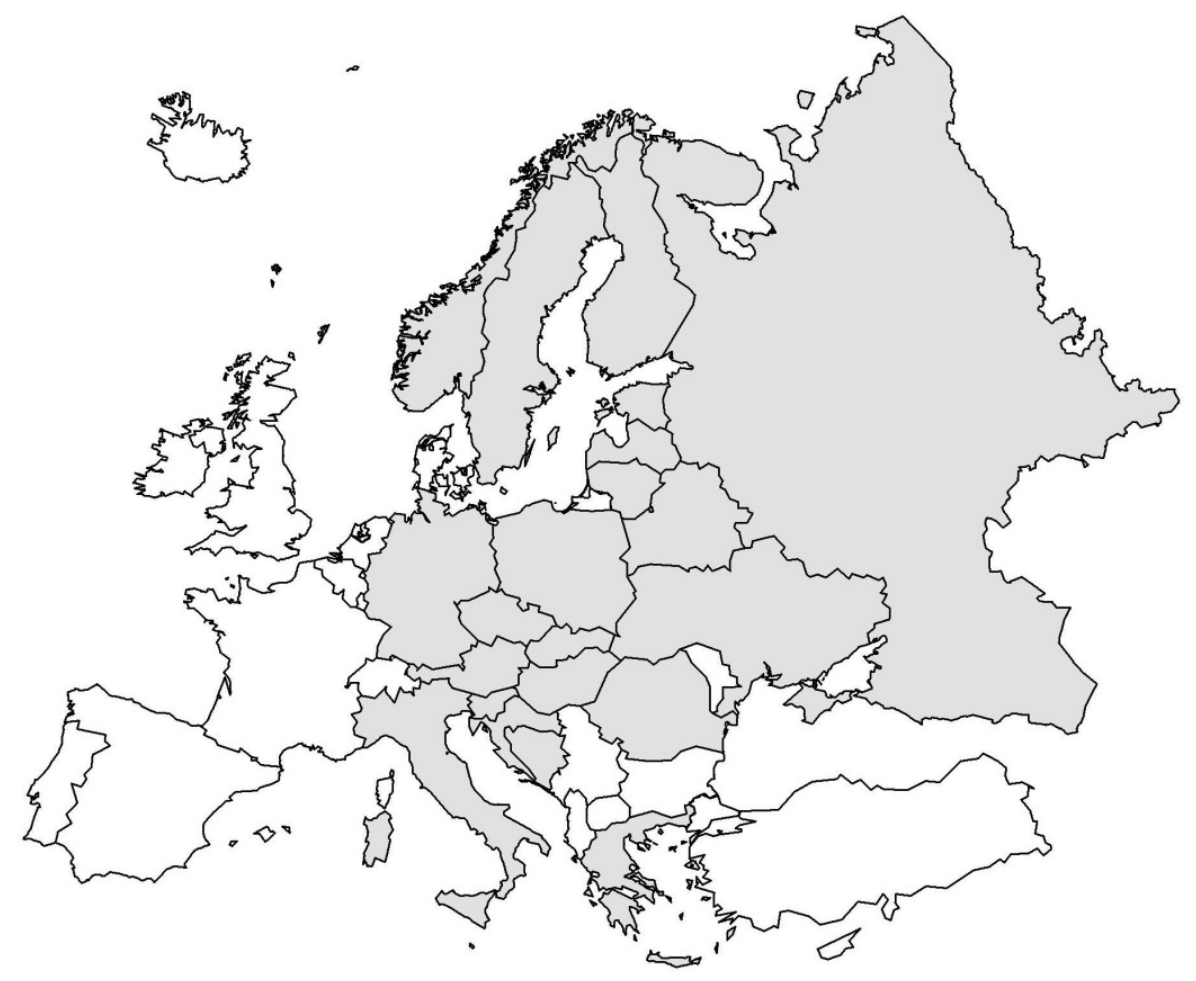

Fig. 1. Distribution of Scardia boletella in Europe (after Gaedike 2011, shaded areas indicate countries where the species was recorded).

In Asia S. boletella is known from few localities in Siberia and the Russian Far East - in the Minussinsk Region, e.g.: Lake Tiberkul in Krasnoyarsk Krai (Central Siberia), Irkutsk Oblast and the Sayan Mts (Koshantschikov 1923, Zagulajev 1973, Robinson 1986).

In Poland $S$. boletella is rarely recorded and known from scattered localities. A few historical data comes, e.g. from the vicinity of Rytro (Schille 1915, Romaniszyn \& Schille 1931) and of Ustron (Toll 1950), where the species was recorded before 1950. The species was also found in the vicinity of Kraków, in the Beskid Niski and the Bieszczady Mts, as well as in the Bialowieża Forest, the Borecka Forest, the Iława Lake District (Sosny Taborskie Nature Reserve), the Augustowska Forest and the Knyszyńska Forest (Razowski \& Palik 1969, Śliwiński, 1979, Buszko \& Nowacki 2000, Buszko 2004, Pawłowski 2009, Jaworski et al. 2014). As most of the known locations of $S$. boletella in Poland are situated in subboreal forests in the north-eastern part of the country or in its south part - in the mountain forests; the distribution pattern of this species is regarded as disjunctive.

Due to potential various threats for the species it was included in the Red List of Threatened Animals of Poland (Buszko \& Nowacki 2002) with category NT (near threatened species), as well as in the Polish Red Data Book of Animals (Buszko 2004) with category LR (lower-risk species), nevertheless, the species is not protected by law.

The aim of our work is to review the current state of knowledge on the distribution and biology of $S$. boletella in Poland. 


\section{BIOLOGY}

The biology of $S$. boletella is relatively well known. The first data on its ecological characteristics were given by Mitterberger (1910) and Koshantschikov (1923), and supplemented later by Zagulajev (1973). It is currently assumed that in the western part of its distribution the species inhabits mainly deciduous and mixed forests typical for temperate climate.

Larvae (Fig. 2) feed primarily on large fruiting bodies (sporocarps) of several species of arboreal fungi: e.g. tinder fungus (Fomes fomentarius (L.: Fr.) Kick.) or representatives of the two genes Polyporus (P. Micheli ex Adans.) (Polyporaceae Fr. ex Corda) and Ganoderma (P. Karst.) (Ganodermataceae Donk) (Zagulajev 1973, Robinson 1986). Furthermore, they often develop inside decaying wood of deciduous trees, mainly birch (Betula L.), beech (Fagus L.), alder (Alnus L.) and elm (Ulmus L.) (Buszko 2004). Both, standing dead trunks and fallen trees are inhabited (Fig. 3). Larval development in Central Europe takes one year. Trunks or sporocarps inhabited by larvae can be easily detected by the presence of saw dust and frass removed out of the galleries by larvae. Pupation takes place inside larval feeding galleries (Fig. 4), usually inside fruiting body of a fungus, or less often, in the upper layers of wood. Shortly before the adult moth hatch, the pupa emerges from the gallery. Empty pupal case protrudes from the exit hole for a long time, which may also be an indication of the species presence (Figs 5 \& 6). Adults (Fig. 7) are on wings from the beginning of June until end of July. They reach 37-60 mm of wingspan and are active mostly at dusk and night (Robinson 1986, Buszko 2004).

\section{METHODS}

Data on the occurrence of $S$. boletella in Poland were mostly taken from the literature. Besides, we listed data on museal specimens, and new data: our own and those that have been provided to us by other Polish lepidopterologists and come from the years 1988-2014. Most of the specimens were caught with use of the mercury mix-light lamps $250-500 \mathrm{~W}$, as well as in barrier traps installed on the sporocarps of bracket fungi. Voucher specimens are held in authors' collections and museums. Additional data were collected on the basis of the characteristics of larval feeding galleries and the presence of empty pupal cases protruding from bracket fungi, decaying trunks, etc.

Names of zoogeographical regions $(\bullet)$ follow the division proposed in Catalogue of Polish fauna (Burakowski et al. 1990), while the names of physico-geographical mezoregions (-) are based on the Regional Geography of Poland (Kondracki 2002). Locations (-) are assigned to UTM (Universal Transverse Mercator) 10x10 km grid. Abbreviations used in the text are as follows: ISEZ - Museum of Natural History, Institute of Systematics and Evolution of Animals, Polish Academy of Science, Cracow; MIZ - Museum and Institute of Zoology, Polish Academy of Sciences, Warsaw)

\section{RESULTS}

\section{Literature data}

- Pojezierze Mazurskie (the Masurian Lake District):

- Pojezierze Ełckie (the Ełk Lake District)

- Borecka Forest [EE79, EF70] (Buszko 2004)

- Pojezierze Iławskie (the Iława Lake District)

- Sosny Taborskie NR [DE35] (Buszko 2004)

- Równina Augustowska (the Augustów Plain)

- Augustów Forest (Buszko 2004) 
- Podlasie (the Podlasie Lowland):

- Wysoczyzna Białostocka (the Białystok Upland)

- the Knyszyn Forest (Buszko 2004)

- Puszcza Białowieska (the Białowieża Forest):

- Równina Bielska (the Bielsk Plain)

- Czerlonka [FD84] (Śliwiński 1979)

- Białowieża - village, forest inspectorate, [FD94] (Śliwiński 1979)

- Wysokie Bagno NR [FD94] (Jaworski et al. 2014)

- Starzyna NR, Pogorzelce NR [FD73] (Jaworski et al. 2014)

- Bieszczady (the Bieszczady Mts):

- Bieszczady Zachodnie (the Western Bieszczady)

- Połonina Caryńska [FV14] (Śliwiński 1979)

- Zatwarnica - Masyw Smereka [FV15] (Buszko 2004)

- Beskid Wschodni (the Eastern Beskid):

- Beskid Niski (the Low Beskid)

- Wysowa [EV17] (Śliwiński 1979, Pawłowski 2009)

- Beskid Zachodni (the Western Beskid):

- Beskid Sądecki (the Sądecki Beskid)

- Rytro, Rytro-Życzanów [DV78] (Schille 1915, Romaniszyn \& Schille 1930, Śliwiński 1979)

- Beskid Śląski (the Silesian Beskid)

- Ustroń-Równica [CA41] (Toll 1950)

- Wyżyna Krakowsko Wieluńska (the Kraków-Wieluń Upland):

- Garb Tenczyński (the Tenczyn Ridge)

- Zabierzów, Skała Kmity [DA15] (Razowski, Palik 1969)

- Śląsk Górny (the Upper Silesia):

- Wyżyna Olkuska (the Olkusz Upland)

- Dulowa [CA95] (Razowski, Palik 1969)

\section{Unpublished data from the museal collections}

- Bieszczady (the Bieszczady Mts):

- Bieszczady Zachodnie (the Western Bieszczady)

- Baligród-Czarne [EV96], 22 Jul 1954 - 3 exx., 16 Aug 1955 - 1ex.; leg. S. Toll.; coll. ISEZ.

- Dołżyca [EV95], 5 Jul 1967 - 1 ex.; leg. E. Palik.; coll. ISEZ.

- Puszcza Białowieska (the Białowieża Forest):

- Równina Bielska (the Bielsk Plain)

- Białowieża NP, forest compartment 224: [FD95], 24 Jun 1963 - 2 exx., at light.; leg. S. F. Adamczewski; coll. MIZ.

\section{New records}

- Puszcza Białowieska (the Białowieża Forest):

- Równina Bielska (the Bielsk Plain)

- Przewłoka NR ad Czerlonka [FD83] - 1. ex., male, e. 1. Jun 2011, larva collected 06 Apr 2011, leg., cult., det. et coll. T. Jaworski. The specimen was reared from decaying wood of birch (Betula pendula) with fruiting bodies of tinder fungus (Fomes fomentarius). 
- Pojezierze Mazurskie (the Mazurian Lake District):

- Równina Augustowska (the Augustów Plain); the Augustów Forest

- Zelwa [FE58], 13 Jul 2005 - 1 ex., 03 Sep 2007 - 1 ex., 30 Jun 2008 - 1 ex., 29 Jun 2009 - 1 ex., 11 Jul 2010 - 1 ex. Observed by W. Kamocki (unpub. data).

- Płaska [FE47], 10-15 Jul 2005 - 1ex., at UV light; leg. A. Malkiewicz, det. et coll. M. Mleczak.

- Rudawka [FE67], 10 Jul 1998 - 1 ex., male, 15 VII 1998 - 1 ex., male, 10 VII 2000 1 ex., male, leg., det. et coll. W. Zajda. All specimens collected at UV light.

- Pojezierze Olsztyńskie (the Olsztyn Lake District)

- Pelnik [DE46], 12 VII 2004 - 1 ex., female, at UV light; leg., det. et coll. W. Zajda.

- Gamerki Wielkie [DE46] - 3 Jul 2007, 1 ex., male, at UV light; leg., det. et coll. W. Zajda.

- Kotlina Biebrzańska (the Biebrza Basin)

- the Biebrza NP, Grzędy [FE14], 15 Jul 2003 - 12 exuviae in rotten wood of birch (Betula pendula), leg., det. et coll. M. Mleczak.

- Wyżyna Lubelska (the Lublin Upland):

- Równina Łęczyńsko-Włodawska (the Łęczna-Włodawa Plain)

- Macoszyn Duży [FB79], 2, 8, 12 Aug 2006 - 3 ex., at UV light; e. 1. 31 May 2007 - 2 ex., e. 1.08 Jun 2007 - 1 ex., e. 1.22 Jun 2007 - 1 ex., e. 1.26 Jun 2007 - 3 ex., e. 1. 10 Aug 2007 - 1 ex., e. 1.17 Jul 2007 - 1 ex., e. 1.23 Jul 2007 - 1 ex., e. 1.20 Aug 2007 - 1 ex., 01 Aug 2010 - 1 ex. at UV light., leg., cult., det. et coll. M. Hołowiński.

- Beskid Wschodni (the Eastern Beskid Mts):

- Beskid Niski (the Low Beskid Mts)

- Barwinek [EV47], 27 Jul 1988 - 1 ex., at light; leg. P. J. Babula, det. et coll. J. Bury; 29 Aug 2007 - exuviae in the fruiting bodies of tinder fungus (Fomes fomentarius) growing on a trunk of fallen beech (Fagus sylvatica). Observed by T. Olbrycht (unpub. data).

- Mrukowa [EV39], 23 Jul 2014, 1 ex., the eastern slopes of Mt. Świerzowa, ca.700 m a. s. 1. Observed by Jarosław Wenta (unpub. data).

- Wołowiec [EV28], 13 Jul 2009 - 1 ex. at UV light; ca. 590 m a. s., leg., det. et coll. R. Zamorski. The specimen was collected in the mixed forest with beech (Fagus sylvatica) and silver fir (Abies alba).

- Bieszczady (the Bieszczady Mts):

- Bieszczady Zachodnie (the Western Bieszczady Mts)

- southern slope of the Połonina Wetlińska [FV04], pupal exuviae in trunk of fallen beech. Observed by J. Buszko (pers. comm.).

- Zatwarnica [FV15], 1 Jul 2002 - few larvae were observed in the sporocarps of tinder fungus ( $F$. fomentarius), as well as in the decaying wood of beech ( $F$. sylvatica). Additionally, 20 exuviae were observed protruding from the bark and from the sporocarp of $F$. fomentarius, leg., det. et coll. M. Mleczak. (Supplementary data to the paper published by Buszko (2004)).

- Połonina Caryńska [FV14], 2 Jul 2002 - about 30 exuviae protruding from beech $(F$. sylvatica) log infested with fungal hyphae of tinder fungus ( $F$. fomentarius), leg., det. et coll. M. Mleczak. (New data confirming the presence of $S$. boletella in the locality published by Śliwiński (1979)). 


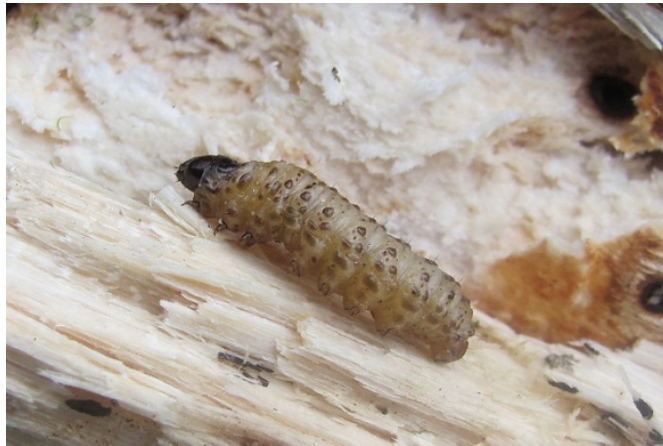

Fig. 2. Larva of the fungus moth Scardia boletella. Photo by M. Hołowiński.

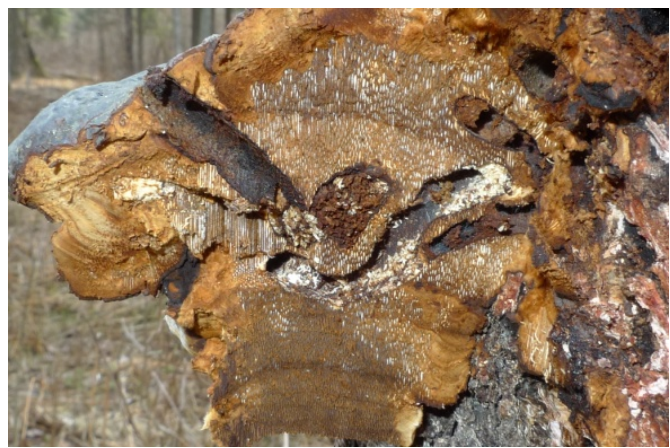

Fig. 4. Scardia boletella - larval galleries in the sporocarp of tinder fungus Fomes fomentarius. Photo by T. Jaworski.

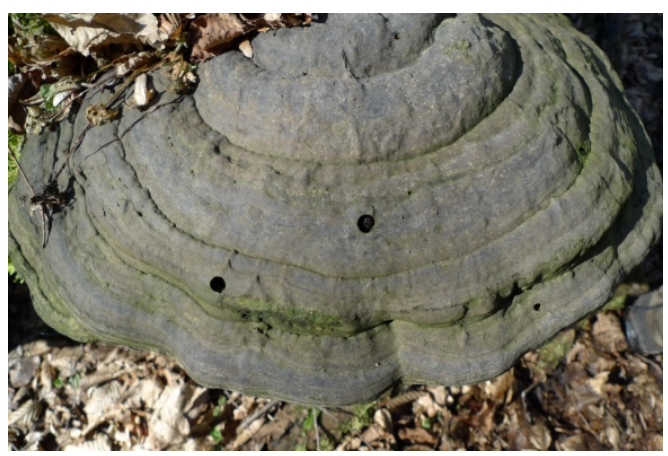

Fig. 6. Scardia boletella - exit holes in the sporocarp of tinder fungus Fomes fomentarius. Photo by T. Jaworski.

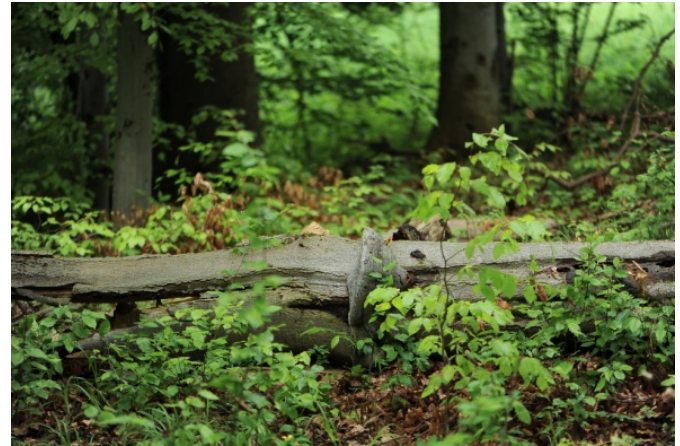

Fig. 3. Biotop of the fungus moth Scardia boletella with fallen beech tree. Photo by J. Bury.

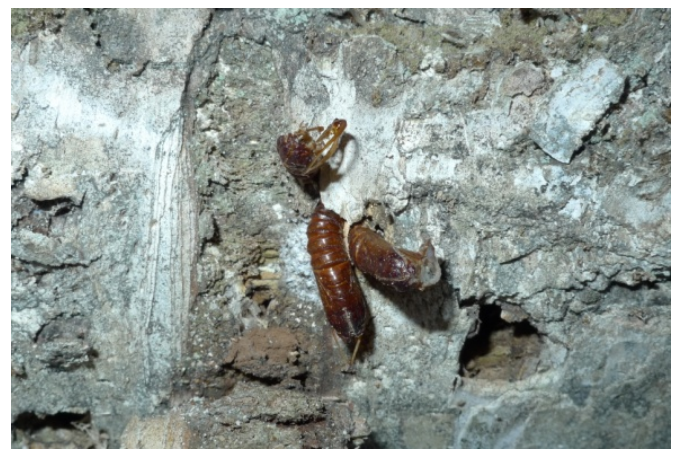

Fig. 5. Pupal exuviae of Scardia boletella. Photo by T. Jaworski.

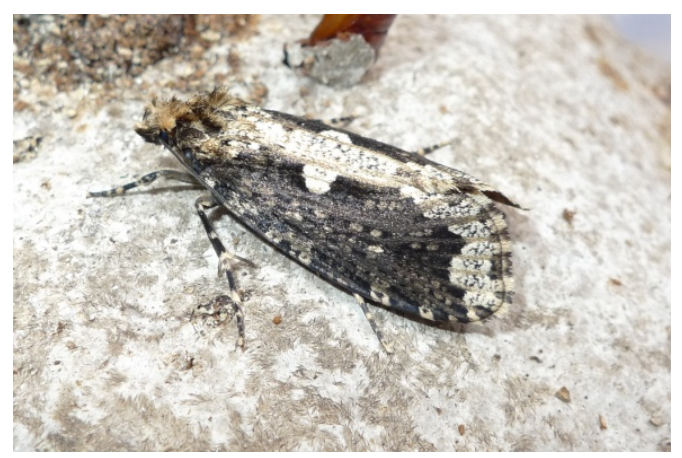

Fig. 7. Scardia boletella - adult. Photo by T. Jaworski.

\section{Summary data on the distribution of Scardia boletella in Poland}

The results of our studies S. boletella showed 27 UTM squares, where the species was recorded (Fig. 8). Most of the newly found localities are situated in the north-eastern (the Bialowieża Forest, the Biebrza Basin, the Augustów Plain and the Olsztyn Lake District) or in the south-eastern Poland (the Low Beskid Mts and the Western Bieszczady Mts). The most isolated locality of $S$. boletella was recently discovered in the eastern part of Poland, in the Łęczna-Włodawa Plain on the Lublin Upland. 


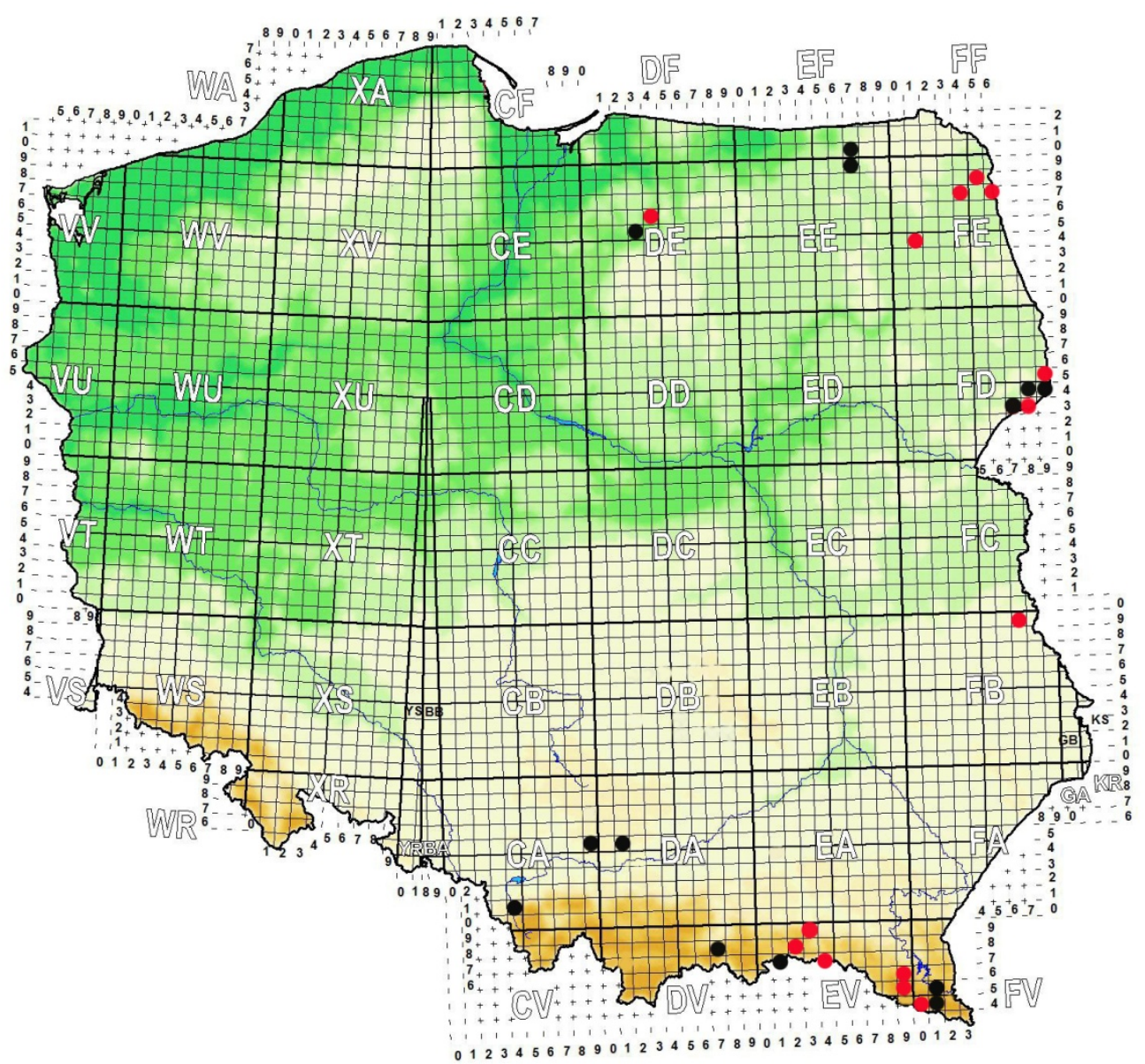

Fig. 8. Distribution of Scardia boletella in Poland: $\bullet$ - published data, $\bullet$ - new data

\section{DISCUSSION}

The fungus moth Scardia boletella, a saproxylic insect, (Speight 1998) is associated with old-growth forests with long continuity of dead wood (Buszko 2004, Fritz 2004). The species inhabits sub-boreal and montane forest habitats of natural character. In Poland, since the first record (Schille 1915) up to 2004, this species was known only from a few, now already partly historical, isolated localities in the north-east and south. Present data continue to support the thesis of the disjunctive distribution pattern of the species (Buszko 2004). The studies conducted in the years 1988-2014 in the eastern part of the country revealed several new localities of $S$. boletella in the area where its occurrence has been found previously. Unforunately, there is no data about its occurrence in the Western Beskid, the Kraków-Wielun Upland and the Upper Silesia after 1979, due to lack of later studies in this area. The new record (UTM FB79) from the Łęczna-Włodawa Plain (the Lublin Upland), in relatively large distance from other known localities in the east of the country, are important for the knowledge on the distribution of $S$. boletella in Poland. 


\section{ACKNOWLEDGEMENTS}

The authors would like to thank those who contributed to this paper. In particular we thank Prof. Jarosław Buszko (Nicolaus Copernicus University, Toruń), Dr Łukasz Przybyłowicz (Institute of Systematics and Evolution of Animals, Polish Academy of Science, Cracow), Dr. Tomasz Huflejt (Museum and Institute of Zoology, Warsaw), Dr Tomasz Olbrycht (Rzeszów University), Jarosław Wenta and Witold Kamocki for providing unpublished data on the distribution of S. boletella in Poland. We also thank Dr Grzegorz Tarwacki (Forest Research Istitute, Sękocin Stary) for providing the distribution map of this species in Europe.

The research was partly funded by the Polish Ministry of Science and Higher Education grant N N309 101839.

\section{REFERENCES}

AARVIK L. \& MidTGAARD F. 1982. The fungivorous moth Scardia polypori Esper (Lepidoptera, Tineidae) new to Norway. Fauna Norvegica (B) 29: 135.

Burakowski B., MroczKowski M. \& Stefańska J. 1990. Chrząszcze - Coleoptera: Cerambycidae i Bruchidae. Katalog Fauny Polski, Warszawa, XXIII, 15: 312 pp.

Buszko J. \& NowACKI J. 2000. The Lepidoptera of Poland, A Distributional Checklist. Polish Entomological Monographs, Poznań-Toruń, 1: 96.

BuszKo J. \& NOWACKI J. 2002. Lepidoptera. In: GŁOWACIŃSKI Z. (ed.), Czerwona Lista Zwierząt Ginących i Zagrożonych w Polsce. - Red list of threatened animals in Poland. Instytut Ochrony Przyrody PAN, Kraków, 264 pp.

BusZKO J. 2004. Scardia boletella (Fabricius, 1794). Mól borowiczak. In: GŁOWACIŃSKi Z. \& NowACKI J. (eds), Polska Czerwona Księga Zwierząt. Bezkręgowce. - Polish Red Data Book of Animals. Invertebrates. Instytut Ochrony Przyrody PAN, Akademia Rolnicza im. A. Cieszkowskiego, Kraków-Poznań, 228-229.

FRITZ O. 2004. Scardia boletella in Halland, SW Sweden - the importance of isolation, habitat area and stand history. Entomologisk Tidskrift 1254: 147-160. [In Swedish with English abstract]

Gaedike R. 2011. Tineidae. In: KARShOlt O., VAn NieuKERKEN E. J. 2011. Fauna Europaea: Lepidoptera, Tineidae. Fauna Europaea, version 2.4., www.faunaeur.org [available: 15.01.2012]

JALAVA J. 1977. Checklist of Finnish Lepidoptera. II + 70 lvs. Helsinki.

JaWORSKi T., HilszCZANSKi J., Plewa R. \& SZCZEPKOWSKi A. 2014. Fungus moths (Lepidoptera, Tineidae) of the Białowieża Forest. Polish Journal of Entomology, 83: 5-21.

KONDRACKI, J. 2002. Geografia regionalna Polski. Państwowe Wydawnictwo Naukowe, Warszawa, 444 pp. Available at http://pl.wikipedia.org/wiki/Plik:Physico-Geographical_Regionalization_of_Poland.png

KoshanTSCHIKOV V. 1923. Material of the Macrolepidoptera fauna of the Minussinsk District (Siberia, Yenisei Province). Ezhegodnik Gosudarstviennogo Muzeya imani N. M. Mart'yanova, Minussinsk, 1: I-VII, 1-10. [In Russian].

KuZNETZOV N. J. 1941, [A revision of the Amber Lepidoptera], Izdatel'stvo Akademii Nauk SSSR, Moscow Leningrad, 136 pp. [In Russian]

Landry J.-F., Nazari V., Dewaard J. R., Mutanen M., Lopez-Vaamonde C., Huemer P. \& Hebert P.D.N. 2013. Shared but overlooked: 30 species of Holarctic Microlepidoptera revealed by DNA barcodes and morphology. Zootaxa 3749 (1): 001-093.

LAŠTŮVKA Z. \& LIŠKA J. 2011. Komentovaný seznam motýlů České republiky. - Annotated checklist of moths and butterflies of the Czech Republic (Insecta: Lepidoptera). Biocont Laboratory spol. s r.o. Brno, 146 pp.

LESAR T. \& GOVEDIČ M. 2010. Checklist of Slovenian Microlepidoptera. Natura Sloveniae 12 (1): 35-125.

MitTERBERGER K. 1910. Beitrag zur biologie von Scardia boletella F. Zeitschrift für wissenschaftliche Insektenbiologie 6: 171-173.

PASTORÁLIS G. 2010. A checklist of Microlepidoptera occured in Slovakia (Lepidoptera: Microlepidoptera). Folia faunistica Slovaca, 15 (9): 61-93.

PAWŁOWSKI J. 2009. Cenne bezkręgowce naziemne Magurskiego Parku Narodowego i terenów ościennych. In: GóRECKI A. \& ZEMANEK B. (eds), Magurski Park Narodowy - monografia przyrodnicza. Krempna - Kraków, 132-146.

PETERSEN G. 1957. Die genitalien der paläarktischen Tineiden. Beiträge zur Entomologie 7: 55-176.

PETERSEN G. 1969. Beiträge zur Insecten-Fauna der DDR: Lepidoptera - Tineidae. Beiträge zur Entomologie19: 311-388.

Petersen G. \& GAedike R. 1979. Beitrag zur Kenntnis der Tineiden-Fauna des mittelmeerraumes. Beiträge zur Entomologie 29: 383-412, figs 1-29.

RAZOWSKI J. \& PALIK E. 1969. Fauna motyli okolic Krakowa. Acta Zoologica Cracoviensis 14: 217-310.

Rebel H. 1901. 2 Theil. Pyralidae-Micropterygidae, 368 pp. In: Staudinger O. \& Rebel H. (eds), Catalog der Lepidoptera des Palaearctischen Faunengebietes. R. Friedländer \& Sohn, Berlin, 828 pp.

RoBINSON G. S. 1986. Fungus moths: a review of the Scardiinae (Lepidoptera: Tineidae). Bulletin of the British Museum (Natural History) Entomology 52 (2): 37-181. 
RoBINSON G. S. 2009. Biology, distribution and diversity of tineid moths. Southdene Sdn Bhd, Kuala Lumpur \& Natural History Museum, London, 143 pp., 16 pls.

Romaniszyn J. \& SCHILle, F. 1931 (1930). Fauna lepidopterorum Poloniae. 2, p.303. Prace Monograficzne Komisji Fizjograficznej / Polska Akademia Umiejętności 7, 358 pp.

SCHILlE F. 1915. Motyle drobne Galicyi (Microlepidoptera Haliciae), Kosmos 1-6: 141-179, 7-12: 307-457.

SPEIGHT M. C. D. 1989. Saproxylic invertebrates and their conservation. Nature and Environment Series, Strasbourg, $42,79 \mathrm{pp}$.

ŚLIWIŃSKI Z. 1979. Rzadkie i nowe dla fauny Polski Tineidae (Lepidoptera). Część II. Polskie Pismo Entomol. 49: 667-670.

TOLL S. 1950. Przyczynek do fauny motyli tzw. drobnych (Microlepidoptera) Beskidu Ustrońskiego. In: REJMENTGrochowska I., Sagan L., Mikulska I., Mikulski J. St. \& Toll S. (eds), Studia nad florą i fauną Beskidu Śląskiego. Wydawnictwa Śląskie PAU. Prace Biologiczne 2: 165-205.

Zagulajev A. K. 1973. Nasekomyje, Tscheschujekrylyje. Nastojaschtschije Moli (Tineidae), 4. Podsemejstvo Scardiinae. In: Fauna SSSR. N. S. 104. Leningrad, 126 pp. [In Russian].

\section{STRESZCZENIE}

\section{[Uwagi o występowaniu rzadkiego gatunku mola borowiczaka Scardia boletella (Fabricius, 1794) (Lepidoptera: Tineidae) w Polsce]}

Mól borowiczak Scardia boletella (Fabricius, 1794) znany był dotychczas z zaledwie kilkunastu stanowisk rozmieszczonych w północno-wschodniej i południowo-wschodniej Polsce. Ze względu na ograniczony obszar występowania i specyficzne wymagania środowiskowe (lasy o charakterze naturalnym, z dużą ilością martwego drewna) uznany został za gatunek zagrożony wymarciem i umieszczony w Polskiej Czerwonej Księdze Zwierząt oraz na Czerwonej Liście Zwierząt Ginących i Zagrożonych w Polsce. W pracy przedstawiono niepublikowane dane i nowe informacje na temat $S$. boletella, zebrane głównie na obszarze północno-wschodniej i południowo-wschodniej Polski w latach 1953-2014. W wyniku badań stwierdzono występowanie gatunku na 14 nowych stanowiskach (oddzielnych kwadratach UTM), w tym po raz pierwszy na Równinie Łęczyńsko-Włodawskiej w obrębie Wyżyny Lubelskiej. Po roku 1979 nie potwierdzono występowania gatunku w Beskidzie Zachodnim, na Wyżynie Krakowsko-Wieluńskiej oraz na Górnym Śląsku. 